\title{
Rare Case of Periampullary Duodenal Carcinoma
}

\author{
Desi Maghfirah, ${ }^{1}$ Azzaki Abubakar, ${ }^{1}$ Fauzi Yusuf, ${ }^{1}$ M. Riswan ${ }^{2}$ \\ ${ }^{1}$ Gastroentero-Hepatology Division, Department of Internal Medicine, Faculty of Medicine, \\ Syiah Kuala University/dr. Zainoel Abidin Hospital, Banda Aceh, Indonesia, ${ }^{1,2}$ Hemato-Oncology Division, \\ Department of Internal Medicine, Faculty of Medicine, Syiah Kuala University/dr. Zainoel Abidin Hospital, \\ Banda Aceh, Indonesia
}

\begin{abstract}
Periampullary carcinoma is a malignancy that appears around the vatteri ampulla. This malignancy can originate from the pancreas, duodenum, and distal choledochal duct. Duodenal cancer is a very rare case, only about $0.3 \%$ of the gastrointestinal malignancies. Reported cases are increasing with the increasing use of esophagogastroduodenoscopy. The most frequently found carcinomas of the duodenum include adenocarcinoma, carcinoid, lymphoma, and leiomyosarcoma. The symptoms of these carcinomas are often not specific so the diagnosis is often late, leading to a poor prognosis. Early diagnosis and proper therapy provide a good prognosis. The case reported here representeda 52-year-old woman presented with hematemesis melena, anemia, jaundice, epigastric mass, right hypochondrial pain, and weight loss. From the esophagogastroduodenoscopy, the mass was found to obstruct half of the duodenum lumen and bleeding, which was easily triggered, was observed in the second part of the duodenum. CT scan revealed a mass in the head of the pancreas with gall bladder hydrops and obstruction of the intra and extra-hepatic billier system. After a Whipple operation Laparotomy, the histology showed papillary adenocarcinoma duodenum. Patients then underwen chemotherapy with 5 fluorouracil regimen. Patient's clinical condition is currently improving and no complaint is conveyed by the patient.
\end{abstract}

Keywords: Adenocarninoma, duodenal carcinoma periampullary, whipple

\section{Kasus Langka: Karsinoma Duodenum Periampulari}

\begin{abstract}
Abstrak
Karsinoma periampulari adalah keganasan yang muncul disekitar ampula vatteri. Keganasan dapat berasal dari pankreas, duodenum dan duktus koledokus bagian distal. Kanker duodenum kasus yang sangat jarang, sekitar 0,3\% dari keganasan gastrointestinal. Laporan kasus meningkat seiring berkembangnya penggunaan esofagoduodenoskopi. Karsinoma duodenum yang sering dijumpai adenokarsinoma, disusul karsinoid, limfoma, dan leimiosarkoma. Gejala sering tidak spesifik sehingga diagnosis sering terlambat dan memberikan prognosis yang jelek. Diagnosis dini dan terapi yang tepat memberikan prognosis yang baik. Dilaporkan satu kasus wanita 52 tahun, datang dengan hematemesis melena, anemia, jaundice, massa epigastrium, nyeri hipokhondrium kanan, dan penurunan berat badan. Pada esofagoduodenoskopi ditemukan massa memenuhi setengah lumen duodenum, mudah berdarah pada second part duodenum. CT Scan ditemukan massa di kaput pankreas dengan hidrops gall bladder serta obstruksi sistem billier intra dan ekstra hepatik. Dilakukan laparatomi Whipple's operation, sitologi jaringan hasilnya papillari adenokarsinoma duodenum dan dilanjutkan kemoterapi dengan regimen 5 fluorourasil. Saat ini kondosi pasien membaik dan tidak ada keluhan.
\end{abstract}

Kata kunci: Adenokarsinoma, karsinoma duodenum periampulari, whipple

Corresponding Author: Desi Maghfirah, Gastroentero-Hepatology Division, Department of Internal Medicine, Faculty of Medicine Syiah Kuala University, Banda Aceh, Jl. Teuku Tanoh Abee, Kopelma Darussalam, Syiah Kuala, Banda Aceh, Indonesia, Email: desi.avisena@gmail.com 


\section{Introduction}

Primary small intestinal malignancy is a very rare gastrointestinal malignancy. ${ }^{1,2}$ Duodenal carcinoma is more common than jejunum and ileum despite the fact it only contributes $0.3 \%$ of gastrointestinal malignancies. This is because this carcinoma constitutes $50 \%$ of small intestinal malignancies. ${ }^{2}$ Several hypotheses are presented on the low incidence of malignancy in the small intestine when compared to the large intestine. These hypotheses include the followings: higher amount of liquid in the small intestine reduces irritation; short transit time in the small intestine reduces exposure to potential carcinogens; bacterial populations in the small intestine produce less carcinogens; and high concentration of immunoglobulin A-producing lymphoid tissue also influences the incidence. ${ }^{3}$

The clinical manifestations of duodenal carcinoma are nonspecific that diagnosis is often unintentional and late. It is also difficult due to its rare incidence and non-typical clinical manifestations, which is worsened by the fact that patients usually come with nonspecific symptoms without any indication for esophagogastroduodenoscopy. $2,4,5$ This delay in diagnosis makes it difficult to do resection of the primary lesions, leading to poorer prognosis.

Although advances in diagnostic techniques has improved duodenal carcinoma detection, the uniqueanatomyofduodenumandtheunreachable features of esophagogastroduodenoscopy limits the possibility of early diagnosis and curative resection in some patients. The prognostic factors in patients with duodenal carcinoma include total bilirubin, TNM stage, cytology, and direct management of cancer. Of all gastrointestinal malignancies, only $1 \%$ of deaths are caused by duodenal carcinomas. ${ }^{4,5}$ This is due to fact that duodenal adenocarcinoma patients often have poor prognosis due to late diagnosis when early diagnosis and the latest therapy will actually provide a good prognosis. ${ }^{6}$ This case report aims to describe the incidence and early diagnosis of periampullary duodenal carcinoma that enables early treatment and good prognosis.

\section{Case}

A 52-year-old Acehnese woman came to the hospital with a complaint of coffee-black vomiting and asphalt-like liquid feces with sticky consistency and foul-smell since 1 day before coming to the hospital. This condition was actually experienced by patients 2 weeks before this complaint and patient had received treatment for the first complaint. The patient also complained of yellowing in the eye that she observed since 2 months before the visit, which became more apparent 1 week before hospitalization. Patient also experienced brownish-yellow urination; pain in the upper right abdomen that was radiating to the back; decreased appetite since 1 month before hospitalization; and weight loss of $5 \mathrm{~kg}$ for the last 2 months.

Patient's awareness at admission was compos mentis with normal hemodynamics. Physical examinations revealed anemia, jaundice, and an epigastric mass with a diameter of $5 \mathrm{~cm}$ with uneven surface and hard consistency as well as fixed and tender.

Laboratory test results presented a hemoglobin level of $7.0 \mathrm{~g} / \mathrm{dL}$, leukocyte count of $9.200 / \mathrm{mm}^{3}$, hematocrit of $23 \%$, platelet count of $277.000 / \mathrm{mm}^{3}$, blood sedimentation rate of 25 $\mathrm{mm} /$ hour, peripheral hypochromic microcytic erythrocyte morphology, normal leukocyte count, normal platelet count, total bilirubin of $6.58 \mathrm{mg} / \mathrm{dL}$, direct bilirubin of $5.12 \mathrm{mg} / \mathrm{dL}$, aspartat aminotransferase (AST) of $189 \mathrm{u} / \mathrm{L}$, alanin transaminase (ALT) of $175 \mathrm{u} / \mathrm{L}$, alkaline phosphatase of $537 \mathrm{u} / \mathrm{L}$, total protein of $4.5 \mathrm{~g} /$ $\mathrm{dL}$, albumin level of $3.4 \mathrm{~g} / \mathrm{dL}$, and globulin level of $1.1 \mathrm{~g} / \mathrm{dL}$.

The chest X-rays showed normal thorax, heart, and lungs with no metastases. The patient underwent an esophagogastroduodenoscopy examination and a mass was found in the duodenum, which was then sent for biopsy.

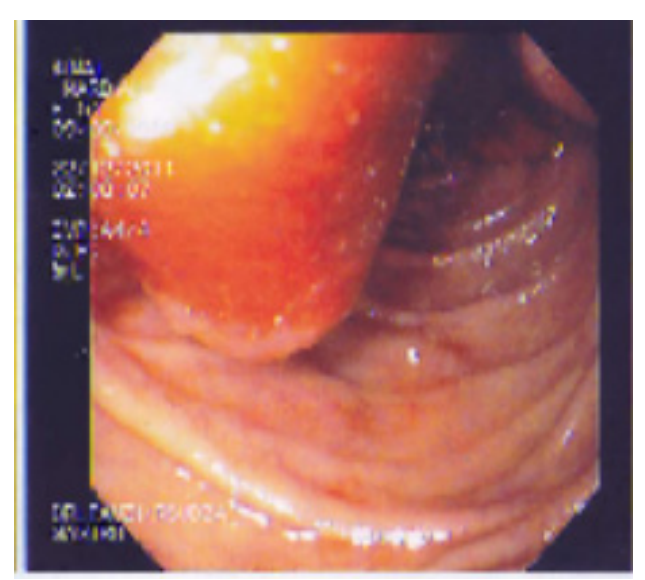

Figure 1 Esophagoduodenoscopy Image

A mass was identified to occupy half of the lumen of the duodenum. This mass bled easily in the second part of the duodenum 


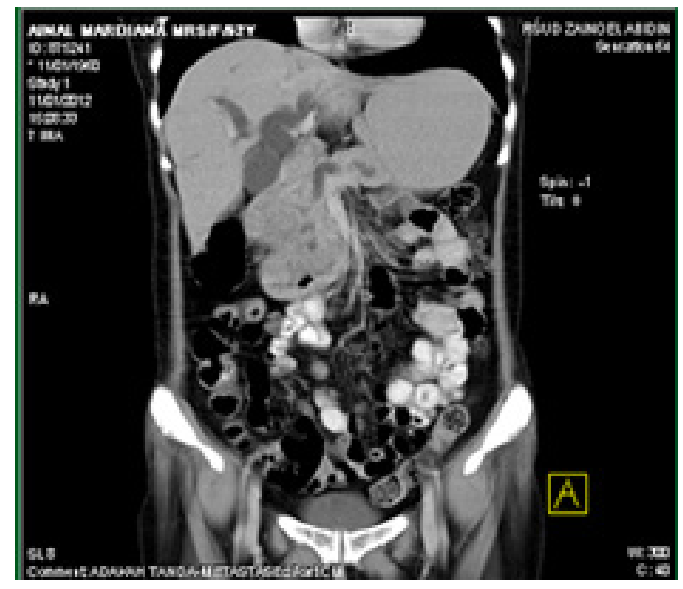

Figure 2 The Mass in the Head of the Pancreas with Gall Bladder Hydrops and Obstruction of the Intra- and Extrahepatobiliary System. The Alleged Mass was in the Ampulla of Vater

The result of biopsy showed mild dysplasia and inflammation. Diagnosis of periampullary duodenal carcinoma was then made based on the anamnesis, physical examination results, and supporting examination results in the form of esophagogastroduodenoscopy biopsy and abdominal computed tomography (CT) scan results.

Patient management at admission consisted of bed rest, soft diet, concentrated red blood transfusion, intravenous proton pump inhibitor (PPI) provision, and mucosa protector provision. After a discussion with the digestive surgeon, a whipple operation laparotomy was performed on the patient. The laparotomy revealed a mass in the duodenum, with a size of $8 \times 6 \mathrm{~cm}$, that involved 2 lymph nodes. Tissue cytology examination result presented that this was papillary adenocarcinoma of the duodenum. After surgery and biopsy, diagnosis was established as stage III periampullary duodenal carcinoma $\left(\mathrm{T}_{4} \mathrm{~N}_{1} \mathrm{M}_{0}\right)$ and a regimen consisting of twelve 5-fluorouracil therapy was performed. After finishing the chemotherapy, patient's clinical condition was good.

\section{Discussion}

Duodenal carcinoma often occurs in the sixth decade and rarely occurs under the age of 50 years with more women experience this condition than men (3:2). Duodenal malignancy is very rare with the third and fourth parts of the duodenum as the most frequent parts to be affected (approximately 45\%). This is then followed by the second part (40\%) and the first part of the duodenum (15\%). ${ }^{4}$ In this case study, a case involving a 52-year-old female patient with carcinoma in the second part of the periampullary duodenum is described.

Duodenal carcinoma is very rare, so the correct diagnosis is often late. ${ }^{7-9}$ Duodenal carcinoma is also often asymptomatic, which contributes to the delay in diagnosis. This asymptomatic nature is due to the ability of the intestinal wall to distend, as well as the presence of natural fluid content in the intestinal cavity. ${ }^{8}$ Carcinoma of the duodenum must be considered in conditions with unexplainable recurrent abdominal pain and intestinal obstruction, especially if no inflammatory bowel disease is found or there is no history of previous surgeries. This condition should also be suspected when there is intussusception in adults and chronic intestinal bleeding. ${ }^{4}$

The manifestations of small intestinal adenocarcinoma are very dependent on the location of the lesion. Lesions in the duodenum are reflected as symptoms of intestinal obstruction that includes both real and subtle gastrointestinal bleeding, abdominal pain, and biliary obstruction. ${ }^{7,8}$ The most frequent clinical manifestations of duodenal carcinoma initially begin with intermittent abdominal pain $(67.4 \%)$, intraabdominal mass (31.2\%), intestinal obstruction $(24.1 \%)$, hematochezia $(21.3 \%)$, jaundice $(16.3 \%)$, fever $(14.2 \%)$, accompanied by intestinal perforation and peritonitis $(5.7 \%)$, upper gastrointestinal bleeding and shock (5\%), and intraabdominal bleeding $(1.4 \%){ }^{9}$ Other symptoms are loss of appetite, diarrhea, anemia, and weight loss. Symptoms appear from 0 to 41 months, but the most common is around 2 months. In a previous study involving 65 cases, the diagnosis is marked by intermittent pain in the abdomen and accompanied by biliary vomiting. ${ }^{4}$ Large lesions will lead to symptoms of about $70 \%$ obstruction such as periumbilical pain, bloating, nausea and vomiting. Complaints of back pain in primary duodenal carcinoma patients are associated with retroperitoneal spread while the back pain mechanisms are associated with tumor bleeding, invasion of enteric ganglia, and serious involvement. Gastrointestinal bleeding is the second most common symptom in benign lesions $(20-50 \%)$ but is less common in severe conditions. Periampullary lesions will give symptoms of jaundice or pancreatitis. ${ }^{5}$ In the reported case, the patient gave symptoms of gastrointestinal bleeding for 2 weeks, jaundice 
for 2 months that became more apparent 1 week before hospitalization, right hypochondrial pain, decreased appetite, and $5 \mathrm{~kg}$ weight loss during the last 2 months.

Physical examination results of duodenal carcinoma are not specific, but in more than $25 \%$ of cases, a palpableabdominalmass was observed. Signs of obstruction are distention, borborygmi, palpable mass, and abdominal muscle stiffness. Fecal blood is found in 10-70\% while some patients experience secondary jaundice that can be caused by a biliary obstruction or due to liver metastasis. In an advanced stage of disease with metastases, cachexia, hepatomegaly, and ascites can be found. ${ }^{3,4}$ On physical examination of the patient in this case study, anemia, jaundice, and epigastric mass with a diameter of $5 \mathrm{~cm}$ with uneven surface and hard consistency that is fixed and tender are identified.

The results of laboratory tests at an early stage are not specific, which may explain the delayed diagnosis. Gastrointestinal bleeding can give a picture of iron deficiency anemia. The duodenal lesions that block the biliary system will increase alkaline phosphatase and serum bilirubin. ${ }^{8}$ On laboratory examination of the patient in this case study, microcytic hypochromic anemia was found due to chronic occult bleading, along with an increase in serum bilirubin with obstruction, and an increase in alkaline phosphatase. In the case of the masses, the ampulla vater had been urged, causing biliary obstruction.

It is difficult to use radiological examination results to distinguish between duodenal carcinoma, chronic duodenal ulcer, and Crohn's disease in patients with chronic enteritis. ${ }^{7} \mathrm{~A}$ plain abdominal radiograph is rarely useful to see the location of the small intestine mass but will provide benefits to examine suspected intestinal obstruction or perforation. In 50-80\% of patients with small intestinal carcinoma, small intestinal follow-through shows an abnormality. Barium enema will show a lesion in the terminal ileum if there is barium reflux in the ileocaecal valve. Video capsule endoscopy (VCE) can detect a small intestinal mass, especially if it cannot be reached by regular enteroscopy examination. Further more, several studies have mentioned that VCE is superior to enteroclysis, enteroscopy, colonoscopy, and CT scan. Doubleballoon endoscopy can also evaluate small bowel mass but is preferred for tissue biopsy and for interventions such as coagulation for lesion bleeding and polypectomy. CT scans with the latest modalities can provide a good tumor picture. Other modalities that can be used are endoscopic ultrasonography and angiography., Frequently used diagnostic techniques are abdominal ultrasonography, followed by abdominal computed tomography, upper gastrointestinal radiography, and endoscopy. Other techniques include endoscopic retrograde cholangiopancreatography (ERCP), superior mesenteric arteriography, colonoscopy, and bone scanning. ${ }^{9}$ Endoscopic biopsy diagnoses many malignant duodenal tumors before surgery with the more distal a tumor more difficult to diagnose before surgery. The accuracy of CT scans in enforcing duodenal adenocarcinoma staging is around 47-61\%, which is merely used to detect mesenteric infiltration and regional lymphadenopathy. ${ }^{2}$ The diagnosis is best made using esophagogastroduodenoscopy and biopsy., ${ }^{3,4}$ Esophagogastroduodenoscopy with biopsy leads to a definitive diagnosis. If the diagnosis is still doubtful, a CT scan of the abdomen can be done to see the malignancy in the duodenal wall and to identify the stage of the malignancy. However, it should be noted that the diagnostic accuracy of abdominal CT scan in duodenal malignancies with masses smaller than $2 \mathrm{~cm}$ is not optimum, with a sensitivity of $94 \%$ and a specificity of $82 \% .{ }^{4}$ In the case reported in this case study, an esophagogastroduodenoscopy and biopsy examination was performed on the patient and the result demonstrated the presence of a mass in the second part of the duodenum that occupied half the intestinal lumen of duodenal carcinoma. On the CT scan of the abdomen, a mass on the head of the pancreas with gall bladder hydrops and obstruction of the intra and extra-hepatobiliary system was also identified. There was also a suspected mass in the ampulla Vater. Therefore, a diagnosis of a duodenal carcinoma that urges the biliary system was made. On chest X-ray, no metastasis was found.

The management of duodenal carcinoma is based on the histopathology type, location, and area. In duodenal carcinoma, the main therapy is tumor resection, which is successful in $40-65 \%$ of cases. ${ }^{9,10}$ The main choice is pancreaticoduodenectomy, or known as the Whipple procedure. In a retrospective study aimed at looking at the results of the primary duodenal adenocarcinoma curative surgery, different types of surgery were compared with 32 patients underwent laparotomy, 18 underwent pancreaticoduodenectomy (Whipple procedure), 6 underwent segmental resections, and 8 underwent bypass procedures. The results demonstrated that the 5-year survival rate 
in the Whipple operation is $27.8 \%$, while the survival rate in segmental resection is $16.7 \%$, showing no significant difference between the two procedures. Whipple operation is the first choice in malignant adenocarcinoma in the first and second parts of the duodenum, and segmental resection is useful in distal duodenal tumors. ${ }^{6,11}$ Pancreaticoduodenectomy (Whipple procedure) is a curative surgery and therapeutic option for tumors located in the first and second parts of the duodenum, giving a better prognosis than in duodenal resection. ${ }^{2,9,11,12}$ Laparotomy is performed for resection and anastomosis of the affected part with a limit of 10 centimeters proximal and distal, including the mesentery and lymph nodes. If curative resection is not possible, palliative resection can be performed with anastomose or stoma. The next option Is that the affected part can be bypassed so it will not give the symptoms of obstruction. With the development of endoscopic expertise and instruments, resection of submucous carcinoma in situ can be done with doubleballoon endoscopy. Cytoreduction surgery (parietal peritonectomy) and Hemomycin C and 5 -fluorouracil chemotherapy can be performed on extensive local duodenal carcinoma, with a life expectancy of 12 to 40 months after surgery. ${ }^{5}$

Chemotherapy is useful for masses that cannot be resected or for patients who are at high risk for recurrence, such as patients who have regional lymph node involvement. This is important to increase life expectancy. The role of adjuvant chemotherapy in duodenal adenocarcinoma is still unclear, Several studies have shown its important benefits in increasing life expectancy. ${ }^{1,13,14}$ Patients who have undergone curative surgery 50-60\% survive more than 5 years. In some studies it is said that chemotherapy is performed on masses that cannot be resected. The mass is reduced so that it can be resected, which increases life expectancy. Chemotherapy can use 5-fluorouracil, capecitabine, and oxaliplatin, but the most commonly used and moar beneficial 5-fluorouracil. Recent data shows that the use of 5 -fluorouracil as an adjuvant chemotherapy, as well as capecitabine and irinotecan for palliative chemotherapy, presents very good results. ${ }^{1,4,13,14}$ For the patient in this case study, laparotomy was performed based on indications of duodenal carcinoma. A mass in the duodenum with a size of $8 \times 6 \mathrm{~cm}$ with the involvement of 2 lymph nodes was found. Whipple procedure was performed, followed by adjuvant chemotherapy with 5-fluorouracil twelve times.
Thestageofthisadenocarcinomaisdetermined based on the seventh edition American Joint Committee on Cancer which follows the TNM staging system. For the T, Tx is assigned if the primary tumor cannot be explained; $\mathrm{T} 0$ if the primary tumor is absent; Tis if the tumor is in situ; T1 if the tumor invades the lamina propria (T1a) and submucosa (T1b); T2 if the tumor invades muscle; T3 if the tumor invades muscle, subserosa, mesentery, or retroperitoneum with a size of less than 2 centimeters wide; and T4 if the tumor has penetrated the peritoneum and invades other organ structures, such as the pancreas. Meanwhile, for the $\mathrm{N}, \mathrm{Nx}$ is assigned when the lymph node involvement cannot be explained; N0 when it does not involve regional lymph nodes; $\mathrm{N} 1$ when it touches 1-3 regional lymph nodes; and N2 if there is metastasis in four or more regional lymph nodes. The $\mathrm{M}$ is categorized as follows: Mx if there is inexplicable distant metastases; M0 if there is no far distant metastasis; and M1 if there is distant metastasis. Stages are then determined as follows: stage 0 for Tis N0 M0; stage I for T1 N0 M0, T2 N0 M0; Stage II for T3 N0 M0, T4 N0 M0; stage III for T0-4 N1 M1; and stage IV for T 0-4 N 0-2 M1. ${ }^{15}$ In this case study, tumors had invaded the pancreas with the involvement of two regional lymph nodes and no distant metastasis, showing that the stage of the adenocarcinoma was stage III-T4 N1 M0.

Primary duodenal cancer is the most common adenocarcinoma (around 50\%) and often occurs in distal duodenum and proximal jejunum. ${ }^{7}$ In a retrospective study on the clinicalpathological analysis of duodenal carcinoma, histopathological examinations were performed. Histopathological examination of duodenal carcinoma is important to see the correct histological subtypes. ${ }^{16,17}$ All patients were diagnosed histopathologically after surgery.

In a study of 141 patients, $61(43.3 \%)$ are found to have adenocarcinoma, 28 (19.8\%) suffer from gastrointestinal stromal tumor (GIST), $17(12.1 \%)$ suffer from carcinoid, 14 (9.9\%) suffer from malignant lymphoma, 10 (7.1\%) suffer from leiomyosarcoma, 6 (4.3\%) suffer from malignant melanoma, 3 (2.1\%) suffer from malignant neurilemmoma, and $2(1.4 \%)$ suffer from fibrosarcoma. Metastatic lymphadenopathy is unexpectedLy found during curative resection surgery in around $37.7 \% .{ }^{9}$ Patient in this case study was found to have duodenal papillary adenocarcinoma.

Although chemotherapy has progressed, the prognosis of patients with duodenal carcinoma is very much dependent on the stage at diagnosis. 
If the diagnosis is established early, patients still have a chance for resection as the main treatment choice. However, $58 \%$ of patients with duodenal carcinoma are diagnosed at an advanced stage (III and IV). 2,13,18,19 The prognosis of duodenal adenocarcinoma is usually poor, with curative resection increases the 5-year life expectancy from $0 \%$ to $54 \%$. Patients without lymph node involvement during surgery has increased 5-year life expectancy of $63 \%$. The discovery of anemia at the beginning of the diagnosis dramatically increases life expectancy; this is associated with diagnosis at an early stage. .,13,14,19,20 $^{2}$

\section{References}

1. Velandia C, Morales RD, Coello C, Mendoza AG, Pérez G, Aguero E. Neoadjuvant chemotherapy in locally advanced duodenal adenocarcinoma. Ecancermedicalscience. 2018;12:816.

2. Han SL, Cheng J, Zhou HZ, Zeng QQ LS. The surgical treatment and outcome for primary duodenal adenocarcinoma. J Gastrointest Cancer. 2010;12(4):243-7.

3. Chandrasegaram MD, Gill AJ, Samra J, Price T, Chen J, Fawcett J, et al. Ampullary cancer of intestinal origin and duodenal cancer - A logical clinical and therapeutic subgroup in periampullary cancer. World J Gastrointest Oncol. 2017;9(10):407-15.

4. Sista F, Santis G De, Giuliani A, Cecilia EM, Piccione F, Leardi S, et al. Adenocarcinoma of the third duodenal portion: Case report and review of literature. World J Gastrointest Surg. 2012;4(1):23-6.

5. Chung WC, Paik CN, Jung SH, Lee K, Kim SW, Chang U. Prognostic factors associated with survival in patients with primary duodenal adenocarcinoma. Korean J Intern Med. 2011; 26(1):34-40.

6. John PK, Kougioumtzopoulou AS, Syrigos KN, Saif MW. Updates in management of ampullary carcinomas updates in management of ampullary carcinomas. J Pancreas. 2014;15(2):140-3.

7. Mayer RJ. Gastrointestinal tract cancer. In: Harrison's Principles of Internal Medicine. $18^{\text {th }}$ ed. New York: The McGraw-Hill Companies.Inc.; 2011. p. 774-5.

8. Ludwig E KR. Tumor of the small intestine. In: gastrointestinal and liver disease pathophysiology Diagnosis Management. Elsevier Inc.; 2010. p. 2145-53.

9. Han S, Cheng J, Zhou H, Guo S, Jia Z, Wang P.
Surgically treated primary malignant tumor of small bowel: A clinical analysis. World J Gastroenterol. 2010;16(12):1527-32.

10. He C, Mao Y, Wang J, Huang X, Lin X, Li S. Surgical management of periampullary adenocarcinoma: defining an optimal prognostic lymph node stratification schema. J Cancer. 2018;9(9):1667-79.

11. Gaspar B,Beuran M,PaunS,Ganescu R, Hostiuc S, Negoi I. Currentstrategiesin the therapeutic approach for adenocarcinoma of the ampulla of Vater. J Med Life. 2013;6(3):260-5.

12. Lundgren S, Elebro J, Heby M, Karnevi E. Mutational landscape in resected periampullary adenocarcinoma: relationship with morphology and clinical outcome. JCO Precis Oncol. 2019;3:1-8.

13. Meijer LL, Alberga AJ, Bakker JK De, Vliet HJ Van Der, Large TYS Le, Grieken NCT Van, et al. Outcomes and treatment options for duodenal adenocarcinoma: a systematic review and meta-analysis. Ann Surg Oncol. 2018;25(9):2681-92.

14. Zaanan A, Costes L, Gauthier M, Malka D, Locher C, Mitry E, et al. Chemotherapy of advanced small-bowel adenocarcinoma: a multicenter AGEO study. Ann Oncol. 2010;21(9):1786-93.

15. Edge SB, Byrd DR, Compton CC, Fritz AG, Greene FL, Trotti A, editors. AJCC cancer staging manual. $7^{\text {th }}$ ed. Philadelpia: Lippincott Raven Publishers; 2010. p 127-9.

16. Fazl QP, Mozzain IK, Shakeel RK, Mubashir AS, Sajjad AD, Abdul Rashid L, et al. Periampullary carcinoma-a rare histopathological variant case report periampullary carcinoma-a rare histopathological variant. J Pancreat Cancer. 2021;7(1):1-7.

17. Williams JL, Chan CK, Toste PA, Elliott IA, Vasquez CR, Sunjaya DB, et al. Association of histopathologic phenotype of periampullary. JAMA Surg. 2017;152(1):82-8.

18. He C, Mao Y, Wang J, Duan F, Lin X, Li S. Nomograms predict long-term survival for patients with periampullary adenocarcinoma after pancreatoduodenectomy. BMC Cancer; 2018;18(327):1-11.

19. Ramfidis VS, Syrigos KN, Saif MW. Ampullary and periampullary adenocarcinoma: new challenges in management of recurrence. J Pancreas. 2013;14(2):158-60.

20. Elebro J. Prognostic factors in periampullary adenocarcinoma A retrospective study over an 11 year period. Lund University, Faculty of Medicine Doctoral Dissertation Series 2016:48. p. 11-65. 